\title{
Inscribing \\ the Other Body
}

Af MeYda YeĞenoĞLU

How do we perceive the veiled

Muslim woman? A way of transgressing the positions for or against the veil is debating the discourse of Enlightenment.

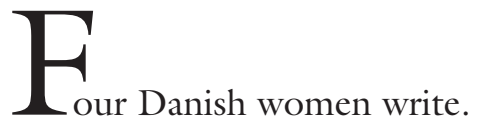

Their title is "The Freedom to Wear a Veil”.

That the veiled Muslim woman by all means should be regarded as oppressed is a myth that ought to be killed. Muslim women's voice is not heard in this matter and they claim that the veil represents freedom and dignity and they do not perceive the veil as inhibiting or oppressive. Quite the contrary: For them the veil guarantees her the full respect of the surroundings and thus must be considered a privilege rather than a burden. But women wearing veils radiate devotion towards their religion. They have chosen the veil as a clear demonstration of their Muslim identity. For the Muslim woman, the veil represents freedom. Only this freedom has another character and expresses itself in another way than that of the West. But must the women of the West be the only ones to define freedom? Are they the only ones who know 
Tørklade demonstrationden 9. januar 2004 på København Rådhuspladsen. Muslimer $i$ københavn demonstrerede $i$ dag mod forslaget om at forbyde religiøs hovedbekladning. Foto: POLFOTO/Jens Dige 
what the right to choose for oneself and to decide over one's own body means? [...] Of course, every woman must have the right to wear a veil as well as the right not to wear one.

(http://www.themodernreligion.com/wome n/w_hijab_dane.htm)

Batool, 21 years old, and Ayisha 19 years old. They challenge the idea that woman are forced to wear the veil. Scarf contributes to creating equality between man and woman. For Batool this prevents her from being seen only as a sex symbol. She says she feels more protected and secure as problems like sexual harassment and rape are avoided. Bergliot Emine, a Norwegian convert, says "Muslim women have more freedom than women in the West. The veil allows me to walk around without being judged by my appearance.

(http://www.themodernreligion.com/wome n/w_hijab_dane.htm)

The editorial of the Qantara News: The Muslim Magazine (January 2004) referring to the French government's plan to ban the hijab in public schools reads as follows:

President Jacques Chirac claims that this is about "conspicuous" religious symbols including Jewish skullcaps, turbans and large crucifixes, but let's face it - the dispute into which it has stepped is about the headscarf [... Mr. Chirac, a Christian wearing a cross is not analogous to a Sikh wearing a turban, a Muslim wearing a scarf or a Jew wearing a skullcap. To observant Muslims, Jews and Sikhs, however, head coverings are obligations. Their observance therefore, falls under the rubric of freedom of expression and conscience, not, as you, would have it, proselytism (gentle convert) [...] A Muslim woman, more often than not, wears the hijab because it is a spiritual expression of her values. Hijab [...] for Muslim women marks their identity and publicly declare their faith. In the face of rising 
Islamophobia, it may even be considered an act of resistance. Can hijab be used by some as a form of oppression? Yes, it can be. While we condemn France, we must also censure the governments of Tunisia, Turkey and other nations who have also taken legal measures to block free religious expression. We question societies where the hijab is imposed in coercive ways. We know this debate isn't over a headscarf. It's about faith, the value of freedom and the consequences of expression. And if we think that resolution of the French controversy will be the end of it, think again - we aint' seen nothing yet.

(http://www.insideout.org/documentaries/ britishjihad/images/qNewsJanuary.pdf)

The predominantly Muslim demonstrators carrying banners that read "My veil, my voice" or "Veil, cross, kippa, leave us the choice."

(http://www.masnet.org/news.asp?id=773)

Fatima Bociha, whose head and neck were covered with a brown scarf, housewife and mother of two from a town of West of Paris said: Liberty, equality, fraternity - apart from women who wear the veil," "The French state wants us to submit, to tell us what to wear and what not to wear," she added. "None of these women here will take their veils off."

(http://www.masnet.org/news.asp?id=773)

Djamila Bekioui, who wore a head scarf in the colors of the French flag, said: "We are being undressed. We have no more freedom. We feel that we are considered second-class citizens."

(http://www.masnet.org/news.asp?id=773)

Marchers were furious about a report commissioned by Chirac suggesting that some Muslim women are forced to wear head scarves by male relatives or to avoid being insulted by men in public, reports the AP.
Jacques Chirac: "Most French people saw "something aggressive" in the veil and that the secular state could not tolerate "ostentatious signs of religious proselytism". (http://www.guardian.co.uk/france/story/ $0,11882,1101321,00 . h t m l)$

The French president's comments followed a petition published by 60 prominent French women, including the actors Isabelle Adjani and Emmanuelle Beart and the designer Sonia Rykiel, published in the French edition of Elle. They call for an outright ban on "this visible symbol of the submission of women". The petition states: "it is an intolerable discrimination against women" and a law is needed to reinforce the principle of a "lay" republic.

(http://www.guardian.co.uk/france/story/ $0,11882,1101321,00$. html)

Mr. Chirac stressed that he had no dispute with the vast majority of French Muslims, but added: "Wearing a veil, whether we want it or not, is a sort of aggression that is difficult for us to accept." A clear majority of both the public and MPs favour a ban, believing that it is the only effective way to defend France's secular republic from the demands of militant Islam.

(http://www.guardian.co.uk/france/story/ $0,11882,1101321,00 . h t m l)$

Saida Kada, co-author of a book defending hijab says: "Headscarf wearing is a religious matter that has nothing to do with politics, but is one of the rules of the Islamic faith. Hijab was being used as a pretext to paper over some social ills inside the French society."

(http://www.parapundit.com/archives/200 3_12.html)

French philosopher Elisabeth Badinter sees headscarfs as a threat to equality for women.: "If we allow women to wear headscarves in state schools, then the republic and French democracy have made clear 
their religious tolerance but they have given up on any equality of the sexes in our country.

(http://www.parapundit.com/archives/200 3_12.html)

One fear is that if headscarves are allowed eventually fundamentalist male Islamists will start punishing any girls and women who do not wear them.

Muslim student Teycir Ben Naser: "I disagree with the proposed ban. I'm in France, I'm in a country that proclaims liberty and human rights and is forcing someone to take off the hijab."

(http://www.parapundit.com/archives/200 3_12.html)

Egyptian filmmaker Safaa Fathy: "The French government is attempting to prevent the growing radicalization of Arab and Turkish Muslims who live in suburban areas. There, the young girls of only eight years old are already forced to wear a headscarf." (http://qantara.de/webcom/show_article.p hp/_c-549/_nr-7/_p-1/i.html?PHPSES$\mathrm{SID}=11544 \mathrm{~d} 45 \mathrm{c} 0 \mathrm{c} 8 \mathrm{bc} 5 \mathrm{f} 740$ )

The Islamic scholar and journalist Navid Kermani: "The French law is very radical, yet it doesn't mean unequal treatment for religions. In fact, it bans all religious symbols from schools. In Germany, the explicit aim is to only remove Islamic religious symbols from the classroom. In my opinion, this is a case of discrimination."

(http://qantara.de/webcom/show_article.p hp/_c-549/_nr-7/_p-1/i.html?PHPSES$\mathrm{SID}=11544 \mathrm{~d} 45 \mathrm{c} 0 \mathrm{c} 8 \mathrm{bc} 5 \mathrm{f} 740$.)

Sebnem Bahadir, a researcher in the area of intercultural communication at the Johannes Gutenberg University in Mains: "The French law limits women's right to personal freedom. [...] The headscarf is not only a religious symbol, but also a cultural phenomenon." (http://qantara.de/webcom/show_article.p hp/_c-549/_nr-7/_p-1/i.html?PHPSES-

$\mathrm{SID}=11544 \mathrm{~d} 45 \mathrm{c} 0 \mathrm{c} 8 \mathrm{bc} 5 \mathrm{f} 740$ )

The Moroccan writer Tahar Ben Jellou, who lives in Paris:

The debate about the headscarf in France is not about taking away Muslim women's right to choose the way they dress. Not at all, it is about a particular dress code for public society. The headscarf is, to my mind, the triumph of ignorance. The law of laicism is very important. Several generations of the French have fought for its implementation in 1905. I am very much opposed to taking a step back by almost 100 years.

(http://qantara.de/webcom/show_article.p hp/_c-549/_nr-7/_p-1/i.html?PHPSES$\mathrm{SID}=11544 \mathrm{~d} 45 \mathrm{c} 0 \mathrm{c} 8 \mathrm{bc5f740 \ldots})$

Qantara editorial reads: "For the founders of the Turkish Republic, France's secularism functioned as a role model; and consequently, no one in Turkey is surprised that the French now want to ban the headscarf from their schools. "

(http://qantara.de/webcom/show_article.p hp/_c-549/_nr-12/_p-1/i/html)

In Turkey, the officially stated goal is to produce "enlightened, educated Turkish women". Kemalists argued that the "The West was victorious because we Muslims were stagnating" and they pointed to the veiling of women as the prime example of this stagnation.

(http://qantara.de/webcom/show_article.p hp/_c-549/_nr-12/_p-1/i/html)

In Britain, the Foreign Office Minister Mike O'Brien: “The British government supported the right of all people to display religious symbols. In Britain we are comfortable with the expression of religion." (http://www.qantara.de/webcom/show_ar- 
ticle.php/_c-549/_nr-11/_p-1/i.html?PH-

PSESSID $=5869$ )

London's Mayor Ken Livingstone was most outspoken about the issue, going as far as implying that France's political elite is playing into the hands of fascist ideologists. On a recent protest march against the ban, Livingstone said: "President Jacques Chirac is playing a terribly, terribly dangerous game in the same way that many politicians felt they could pander to Hitler in the 20s. It (i.e. the ban) is an anti-Muslim measure and will stir up anti-Muslim pressure."

(http://www.qantara.de/webcom/show_article.php/_c-549/_nr-11/_p-1/i.html?PHPSESSID $=5869$ )

Abeer Pharaon, president of the Muslim Women Society in Britain: "Despite the encouraging statements we have heard from the Government, we remain extremely concerned that the rapid spread of this legislation throughout Europe might encourage extremists and Fascists to attack and insult Muslim women in the UK. The hijab is our right, our freedom and our choice."

(http://www.qantara.de/webcom/show_article.php/_c-549/_nr-11/_p-1/i.html?PH-

PSESSID $=5869$ )

Wearing the hijab is not a threat to anyone and does not violate anyone else's rights and freedoms," said Thomson. "Banning the hijab cannot be viewed as necessary in a democratic society in the interests of public safety, for the protection of public order, health or morals or for the protection of the rights or freedoms of others."

(http://www.qantara.de/webcom/show_article.php/_c-549/_nr-11/_p-1/i.html?PH-

PSESSID $=5869$ )

Above all, the modern age is evident in the veil and headscarf's modern functions. In addition to the religious relevance of the veil and the headscarf has cultural, political and social relevance. Inwardly, within
Egyptian, Syrian or Turkish society, they symbolise the claim to justice, a justice between the classes and between the sexes. This is an aspect that is all to easily overlooked in the West. "Islamic clothing" for men and women liberates its wearers from the pressure of having to compete (hopelessly) with people like themselves by wearing expensive clothes, cosmetics and jewellery.

At the same time, it liberates them externally from a social origin that could possibly be considered oppressive. Furthermore, such clothing helps women and girls to make their way in the world of education and work by allowing them to exist in a nimbus of sexual unassailability in a public life that is still dominated by men. From a functional point of view, therefore, it is indeed possible to see the headscarf as the exact opposite of an openly-demonstrative backward attitude, namely as a modern attribute. At the same time, the headscarf remains multifunctional: it is used both as a tool by fathers to deny their daughters higher education and by daughters to wring higher education out of their fathers."

(Sabine Enderwitz, http://www.qantara.de/ webcom/show_article.php/_c-549/_nr-6/ _p-1/i.html)

Najla Ainouz, a 25 year old Moroccan immigrant to Denmark, was fired from her job at the Føtex supermarket for wearing a hijab headscarf in violation of an employment contract that forbids workers from displaying any religious symbols and also forbids really dramatic hair colors and nose rings. Her union sued the supermarket but Denmark's high court ruled against Ainouz and her union.

(http://www.parapundit.com/archives/001 861.html)

Queen Margrethe of Denmark has spoken out against radical Islam and called on Muslim immigrants in the country to im- 
prove their Danish language skills. The queen said, that "people had to take the "challenge" of Islam seriously. We have let this issue float around for too long, because we are tolerant and rather lazy. Muslims should learn Danish properly, so they would not feel excluded from society." (http://news.bbc.co.uk/2/hi/europe/ 4445579.stm)

In the book Margrethe, written by journalist Annelise Bistrup, the queen is quoted as voicing disapproval of "these people for whom religion is their entire life". Calling for opposition to radical Islam, she said: "We have to run the risk of being labelled in an unflattering way, because there are some things for which we should display no tolerance.

(http://news.bbc.co.uk/2/hi/europe/ 4445579.stm)

Turkey, 1920s: Mustafa Kemal, the founder of Turkish Republic, issued reforms about women's dress and men's hat which were considered as the most visible and outward indicators of one's allegiance to "civilized" West or "barbaric" East. The goal was to construct modern Turkish identity as opposed to backward Ottoman identity, make Turkey a civilized/modern nation and yet retain the native/original culture, to de-establish Islam and limit its power to matters of belief and worship. The unveiling of woman was a practical medium to signify all these issues at once. For Kemal, the practice of veiling was a particularly backward practice and thus he targeted it as an issue needing immediate "remedy." The regulation of the existing codes of dressing was an indispensable element in Kemal's attempt for modernization.

Algeria under colonization: The colonial administration in Algeria insisted on unveiling women, for the veil was seen as the concrete manifestation of the colonized's resistance to an imposed reciprocity.
Women's insistence on wearing the veil meant the colony's resistance to being colonized.

The campaign against the veil was intensified in the 1930s with the French administration's campaign to encourage the education of women. In May 13, 1958, a group of colonial generals accomplished a coup and displaced the civilian governor of Algeria. The same day, they organized a rally in front of the Governor's Palace and featured the unveiling of a group of Algerian women. The staging of such a performance was meant to symbolize the conquest of the last but foremost obstacle in the total capitulation of Algerian culture. Such a performance was supposed to symbolize that "the whole of Algerian society was offering itself, naked and willingly, to the embrace of the European society" (Bourdieu 1961).

For the FLN, women were the true guardians of their authentic traditions and identity. Algerian nationalists were generally in favor of emancipation, but they also insisted that women in their traditionalist role had preserved the native traditions and what they wanted was a free Algerian not a free French woman.

Turkey, 1999: Merve Kavakci, a women wearing headscarf, was elected as an M.P in the 1999 elections from Istanbul but later she was banned from running office for five years because her citizenship was revoked and she was accused of instigating hatred amongst people and striving to destroy the laic structure of the Turkish state. Kavakç> says: "Laic states like France and Turkey can easily be defied if they claim to be both democratic and adherents to values of human rights - which is the case in both of these countries. The caveat with such a system is its proclivity towards a tyrannical reign like anti-religious fascism."

(http://www.insideout.org/documentaries/ britishjihad/images/qNewsJanuary.pdf) 
The debate over the veil has been either an issue of freedom and dignity, devotion to religion, a demonstration of one's religious and cultural identity. It has also been framed as an issue of whether one feels more secure and protected with the veil and whether Muslim/veiled women have more freedom than unveiled/Western women. It is seen as a right to choose and part of freedom of expression and conscience and an expression of one's spiritual values. It is even seen as an act of resistance in the wake of rising Islamophobia. It is part of freedom of religious expression. Its prohibition has been debated as a matter of religious intolerance and discrimination. The question of liberty and human rights are the terms that govern the above position.

Or the veil is seen as inhibiting and oppressive; as something imposed on women in a coercive way and so it is regarded as a visible symbol of women's submission and an undisputable sign of the discrimination against women. Moreover, it is regarded as an attack on secularism by the demands of militant Islamism. A sign of backwardness and resistance to modernization and civilization. It is regarded as an indication of triumph of ignorance as it is claimed that it attempts to step back from laicism. As women are forced to wear it, it limits their rights and freedom to choose.

The characterizing features of the prevalent discourses on the veil in today's European public sphere as well as in colonial times are a by-product of the articulation of elements of liberal humanism, feminist individualism and the principles of the Enlightenment project. These discourses inscribe the issue of the veil within the terms of the right and freedom of choice. Veiling or unveiling, depending on one's political allegiance, becomes either an issue of liberation and a right to decide and personal freedom. Or a sign of oppression and lack of freedom in individual liberties. But what is common to both the anti-veil and pro- veil position is the notion of a free individual, making rational choices about herself. So, despite the apparent dissimilarity between the two positions, they do share the same universe as both positions are based on the same modernist notion of the individual and body. This modernist notion of the individual, who aspires to be free, rational and liberated, is one of the fundamental values valorized by the liberal ideology that is fashioned by the Enlightenment project. Enlightenment marks the constitution of the subject, human and individual. What is seriously missing from the discussions of the veil in the European public sphere is an understanding, which sees such cultural, religious practices as ways of inscribing women's bodies in particular ways.

I would like to suggest that, if we remain within the terms of this liberal, Enlightenment rhetoric, we will remain blind to the inscription of bodies through various practices of adornment, clothing, cosmetics and so on. In other words, what I am suggesting is that, we need to free our discussion of veiling from the terms of liberal ideology, which cannot comprehend the veil other than within the problematic of free choice versus oppression/imposition. Therefore, the veil has to be liberated from this liberalist dilemma and needs to be seen as a practice of embodiment.

How can we think of the veil and embodiment together? Can we read veiling simply as an instrument of oppression? Or should we conceive of veiling and unveiling in terms of the bodily affects such practices imply? How should we conceptualize the relation between discourses, practices, norms about dressing and the embodiment? What kind of an understanding of body can enable us understand corporeality in culturally and sexually specific terms and in their concrete specificities? What kind of presumptions about subjectivity and body need to be scrutinized and challenged so as to posit the bodily roots of subjectivity?

Feminist theory provided fruitful discus- 
sions for liberating the body from the grips of the metaphysics. In these discussions emphasis is placed upon the need for a materialist conception of the body and for the embodied nature of subjectivity and sexual difference. Those who emphasize the usefulness of poststructuralism for feminist theory and the need for understanding the body as an effect of historically specific technologies of power offer fruitful horizons to think the veil differently. Michel Foucault's analysis shows how the body does not stand in an external relation to power, but is marked, stamped, invested, acted upon, inscribed and cultivated by historically contingent nexus of power/discourse, that is, how it is brought into being by power. Following Foucault, we can suggest that power is the productive principle through which the materiality of the subject is constituted. Such a constitution takes place through processes of training, shaping, cultivation and investment of the body by power. Power takes the body as its target, the object, the medium to extract information so as to transform, remake, reinscribe and subject it to the functioning of power. However, the subjection and control of the body within the field of power must not be understood through a model of repression. The Foucauldian approach challenges the understanding of subjection of the body to power as a simple process of subordination or as a repression of its desires and instincts. Following the Foucauldian insight we can suggest that, "this 'subjection', or assujettisement, is not only a subordination but a securing and maintaining, a putting in place of a subject, that is, subjectification. Therefore, the formation and regulation of bodies in their materiality cannot be understood separately from their subjectification, for subjectification implies a simultaneous creative and coercive process. A useful force only if it is both a productive body and a subjected body. (Foucault 1977).

Understanding power as a productive and formative process requires questioning the presumptions of the paradigms, which conceive the subject in terms of the primacy of mind and the concomitant assumption of the body's naturalness and pre-cultural status. Bodies are not ahistorical, precultural or pre-social: They are in no way natural, but always-already marked, inscribed and engraved by social practices. In emphasizing that bodies cannot be adequately understood if they are seen as impregnable by cultural, social, and historical factors, we should underline the fact that power produces bodies always as a determinate type; bodies are neither universal nor neutral, but always culturally, sexually, racially specific. To liberate the body from its colonization by the paradigms which privilege the mind in understandings of subjectivity will not only enable us to posit its materiality, but also foster an understanding of bodies in their sexual, cultural and racial specificities. Raising the question of the specificity of the body requires simultaneously raising the question of its materiality, for questions regarding the differences between bodies can only be meaningfully asked if the corporeality of bodies is no longer seen as a biological, natural and neutral, but always as a product, an effect of power relations which constitutes them in their specificities.

To be able to develop a materialist conception of the body, the body as an affect of power/knowledge nexus, we need to formulate theories that have the force and capacity to overcome the various dualisms through which the body is traditionally envisioned. Among the most pertinent oppositions that need to be displaced for exploring and developing an understanding the body other than the one offered by traditional philosophical and phallogocentric understanding are the body-mind, natureculture, and discourse-referent. To argue for the constituted nature of the body does not imply that the effectivity of discourses on the body should be seen as limited to 
the shaping and influencing of the mind, for such an understanding implies that there is a biological, natural, real, material body on the one hand, and there are various cultural and historical representations of it. The controlling, making and marking of the bodies are not realized through the control of ideas. Such inscriptions are not merely added to a body that is naturally and biologically given. If a materialist notion of corporeality implies that power operates by constituting the subject's biological make-up, then positing the body's naturalness as prior to its inscription needs to be seen as an effect of power. The notion of a biological or natural body is the very discourse, which neutralizes and universalizes the cultural, racial, sexual specificity of different bodies. In fact such a universalizing and neutralizing gesture is the gesture of phallogocentricism, which preempts the embodied nature of masculine subject, a gesture that conflates the human with masculine and thus marks women as the site of embodiment.

The notion of the body as the stuff of inscription of social norms, practices and values can be extended to the discussion of veiling and the positioning of Muslim women's bodies within various representations. We can bring a different perspective to the taken-for-granted presumption about the cruelty and primitiveness of veiling when we recognize the possibility of inscription of bodies through various practices of adornment, clothing, cosmetics and so on. If veiling can be seen as a specific practice of marking and disciplining the body in accordance with cultural requirements, so can unveiling. In other words, both the practice of veiling and unveiling are culturally specific procedures of corporeal inscriptions, conditioned by specific cultural histories. What needs to be examined here is the presumption of the truth and naturalness of the unveiled body that the prevalent anti-veil discourse is predicated upon. However, if veiling is a specific practice of situating the body within the prevailing exigencies of power, so is unveiling. Therefore, the unveiled body is no less marked or inscribed; rather a whole battery of disciplinary techniques and practices has produced unveiled women's bodies and therefore not-to-veil needs to be seen as one among many practices of corporeal inscriptions. In other words, there is nothing natural about unveiling and therefore not-to-veil is no less inscriptive than being veiled. Not-toveil, like veiling, is another way of turning the flesh into a particular type of body. However, the body that is not veiled is taken as the norm for specifying a general, cross-culturally valid notion of what a feminine body is and must be. Hence the presumption of the naturalness of not-to-beveiled has come to secure the truth of bodies and is used as the universal norm to yield Muslim woman as a knowable and comprehensible entity. In other words, it is the naturalness and truth of the unveiled body, which legitimates and endorses colonialist sentiments and certitude in the necessity of interventionist actions against Muslim women's veiling. Moreover, the beliefs and values about not veiling are no less incorporated to the existential, embodied being of unveiled women, the specificity of this inscription is effaced in colonialist representations and the beliefs and values that codify and mark unveiled women's bodies have come to secure the truth of Western women's bodies in general. They are used as the explanatory norm to unravel the desires and pleasures of bodies that are located in other histories and cultures: one culture's codings of bodies become the template through which all bodies are conjured. Veiling is one of those practices that irritates and disturbs the Western especially in feminist cognizance; it is one of those practices, like incision and various other body markings that incite anxiety. Practices and processes by which other bodies are marked have appeared to the Western eye to be excessively violent, barbaric and as 
the indisputable document of cruelty Muslim women are subjected to. The disciplinary techniques and procedures that inscribe, control and train other-Muslim bodies are distinguished from the "civilized", Western techniques and practices by the degree of barbarism inflicted upon the former. Emphasizing the culturally specific nature of embodiment reveals, however, that the power exercised upon bodies by veiling is no more cruel or barbaric than the control, supervision, training, constraining bodies by other practices, such as bras, stilettos, heels, corsets, cosmetics and so on.

If bodies are produced through various cultural practices, then their desires, pains and pleasures must be specific to particular cultures. If this is so, then the truth of veiled women and their bodies cannot easily be retrieved within the terms of the colonialist discourse, for it is a discourse which is already a cultural product, enabled and conditioned by dominant discourses. The foreignness of the veiled body is assumed to be deciphered by being translated and neutralized within an economy of universal truth.

The body is the medium through which power operates and functions and knowledge is the major instrument power utilizes for this operation. It is also through the exercise of power that knowledge from bodies can be extracted, and this knowledge in turn functions as the main instrument in the control, inscription and training of bodies. Following Foucault on the issue of power/knowledge nexus, we can suggest that power and knowledge are the condition of existence of each other. Power is transformed, altered, modified, intensified in accordance with the diversification and alterations in the order of knowledges. By conceptualizing the interlocking of bodies and discursive regimes, Foucault enables us to understand the process of subject constitution in modern society. As a body subject to modern, colonial technology of power- knowledge, the colonized should be produced as a new body and mind with certain skills, characteristics and form; she/he needs to be re-made. But to understand this re-mapping and re-territorialization, we need to position the body of the other within a frame, which can account for it as a historical and cultural effect of power. The other's particular mode of corporeality is an important site for colonial inscriptions of power, as the desire to get hold of the native women's body is evoked as the metaphor of colonial occupation (hence French colonialism's obsession with unveiling the Algerian women). If veiling is one of the instruments of coding the Muslim women's body and her embodied nature of subjectivity, then what bodily implications might unveiling have for these women? The following quotation from Frantz Fanon is worth citing here as he describes the bodily transformations an Algerian woman undergoes when she is unveiled:

The body of the young Algerian woman in traditional society is revealed to her by its coming to maturity and by the veil. The veil covers the body and disciplines it, tempers it, at the very time when it experiences its phase of greatest effervescence. The veil protects, reassures, isolates. One must have heard the confessions of Algerian woman or have analyzed the dream content of certain recently unveiled women to appreciate the importance of the veil for the body of the woman. Without the veil she has an impression of her body being cut up into bits, put adrift; the limbs seem to lengthen indefinitely. When the Algerian woman has to cross a street, for a long time she commits errors of judgment as to the exact distance to be negotiated. The unveiled body seems to escape, to dissolve. She has an impression of being improperly dressed, even of being naked. She experiences a sense of incompleteness with great intensity. She has the anxious feeling that something is unfinished, and along with this a frightful sensation of disintegrating. The absence of the veil 
distorts the Algerian woman's corporeal pattern. She quickly has to invent new dimensions for her body, new means of muscular control. She has to create for herself an attitude of unveiled-woman-outside. She must overcome all timidity, all awkwardness [...] and at the same time be careful not to overdo it, not to attract notice to herself.

\section{The Algerian woman who walks stark naked into the European city relearns her body, re-es- tablishes it in a totally revolutionary fashion. (Fanon 1965; emphasis mine)}

Fanon draws our attention to one of the most striking instances of the cultural violence of colonialism. He also suggests that the veil is not simply an attire that covers the woman's body, but it is what transforms a little girl into a woman in Muslim society. It is because her mature female body is made by the veil that unveiling her is not simply an uncovering, or change of dress, but peeling her skin off. In this sense, the so-called dream hallucinations which she experiences are very real sensations which have parallels in the everyday, "normal" experiences of crossing a street or simply walking out in the street. As Kaja Silverman (1986) notes, clothing, (and veiling should be seen as one particular style among many) has the force of constituting identity and corporeality:

Clothing exercises as profoundly determining an influence upon living, breathing bodies $[\ldots]$ affecting contours, weight, muscle development, posture movement and libidinal circulation. Dress is one of the most important cultural implements for articulating and territorializing human corporeality - for mapping its erotogenic zones and for affixing a sexual identity (ibid.).

Following Silverman, then we can see the veil as not something that is external to the identity of Muslim women, but as a fundamental piece conjoined with the embodied subjectivity of Muslim woman. If we cannot comfortably assume that her body is inside the veil or the veil is something that is outside of her body and hence does not function merely as a body cover, can we then think of bringing this body outside the veil (as colonial or imperial feminism desires) without at the same time exercising another form of power? If the veil is part of her body, part of her being-inthe world, then it differs from a simple cover that has an inside and an outside; its "function" cannot be captured by such categorical oppositions. As the in-between of outside and inside, the veil makes both inside and outside possible. There would indeed be no inside-outside without the veil. It is what constructs a before and a behind. But there would also be no veil without the inside and outside that it makes possible by separating and constructing. In the ambiguous position it occupies, the veil is not outside the woman's body. Nor is she the interior that needs to be protected or penetrated. Her body is not simply the inside of the veil: it is of it; "she" is constituted in (and by) the fabric-ation of the veil. Being an undecidable textile, the veil interweaves the woman's skin with its threads; as the sign of fusion it stitches together the epidermis of woman with cultural codings. It is both her identity and her difference, or it is what makes her identity different. The veil is that which produces woman, or difference; it is spacing, differánce.

By assuming an interiority that is concealed by the veil, colonial gesture articulates itself in terms of the Western metaphysical or philosophical oppositions between origin and representation, essence and appearance, identity and difference. A number of writers have pointed to the fundamental continuity and homology between the structure of Western metaphysics and phallocentric order. There is thus a fundamental affinity or a chain of equivalence among Western philosophical, colonial and patriarchal discourses. This implies that any serious challenge to patriarchy cannot overlook questions of colonial dis- 
course, for both are placed within a larger cultural project whose fundamental philosophical assumptions need to be questioned. To assume that these questions are separate from each other is the very illusion that the categorical-analytic discourse of Reason produces. A feminist discourse which tries to emancipate others should in the first place learn how to question this very process of othering, and what this implies for its "own" "identity" (that is to say, whether a discourse can be both a discourse of identity and sameness under the governance of Reason and Progress and a feminist one at the same time). Such a questioning should of course include the questioning of the very opposition between inside and outside as one of the fundamental cultural oppositions, which construct femininity itself.

The veil is dress, but a dress, which we might consider as articulating the very identity of Muslim women. Only if we see the veiling of woman in Muslim culture as a unique cultural experience, then we can actually learn about what it is to veil or unveil as woman, rather than simply re-setting the liberal scene and repeating commonsensical and cliché standards in the name of universal emancipation. I want to argue here that such commonsensical and cliché standards may not be so commonsensical and cliché after all. They may, on the contrary, be part of a colonial gesture that is hard to define as colonial because, especially in a now de-colonized world, it articulates itself as a universal, and politically and morally correct task.

\section{Noter}

1. Paper presented at the Conference Gender, Body and Sexuality in Europe, Copenhagen, April 29, 2006

\section{REFERENCES}

- Bourdieu, Pierre (1961): The Algerians, Beacon Press, Boston.

. Foucault, Michel (1977): Discipline and Punish:

The Birth of Prison, Penguin Books, Har-

mondsworth.

- Fanon, Frantz (1965): A Dying Colonialism, Grove Weidenfeld, New York.

- Silverman, Kaja (1986): "Fragments of a Fashionable Discourse", in Tania Modleski (ed.): Studies in Entertainment: Critical Approaches to Mass Culture, Indiana University Press, Bloomington and Indianopolis.

Meyda Ye ğenoğlu, professor i sociologi, Middle East Technical University, Ankara 